\title{
Synthesis of Anacardic Acids, 6-[8(Z),11(Z)-Pentadecadienyl]salicylic Acid and 6-[8(Z),11(Z),14-Pentadecatrienyl]salicylic Acid
}

\author{
Mitsuru Satoh,* Naoki Takeuchi, Takeshi Nishimura, Takashi Ohta, and Seisho Tobinaga \\ Showa Pharmaceutical Univercity, 3-3165 Higashitamagawagakuen, Machida, Tokyo 194-8543, Japan. \\ Received June 19, 2000; accepted October 12, 2000
}

11-Chloro-3-methoxy-2-undecenal was synthesized from 8-bromooctanol, and an annelation reaction with this aldehyde and ethyl acetoacetate proceeded to give the ethyl 6-(8-chlorooctyl)salicylate. Ethyl 6-(8chlorooctyl)salicylate was converted to ethyl 6-(7-formylheptyl)-2-methoxybenzoate through the iodide after protection of the phenolic hydroxyl group. Finally, the Wittig reaction with the aldehyde and triphenylphosphonium iodides in the presence of $\mathrm{BuLi}$ gave the methoxybenzoates, and then treatments of these methoxybenzoates with $\mathrm{BBr}_{3}$ in $\mathrm{CH}_{2} \mathrm{Cl}_{2}$ and $10 \% \mathrm{NaOH}$ in ethanol gave 6-[8(Z),11(Z)-pentadecadienyl]salicylic acid (anacardic acid 3) and 6-[8(Z),11(Z),14-pentadecatrienyl]salicylic acid (anacardic acid 4) which were isolated from plants of the anacardiaceae.

Key words anacardic acid; synthesis; annelation reaction; aldehyde

It is known that constituents of cashew-nut shells (Anacardium occidentate, anacardiaceae), anacardic acids are a mixture of four 6-alkylsalicylic acids, 6-pentadecylsalicylic acid (1), 6-[8(Z)-pentadecenyl]salicylic acid (2), 6-[8(Z),11(Z)-pentadecadienyl]salicylic acid (3), and 6-[8(Z),11(Z),14-pentadecatrienyl] salicylic acid (4) (Chart 1). ${ }^{1)}$ These compounds have shown various physiological activities, inhibition of prostaglandin synthesis, antifeedant activities and antitumor activities such as those described in refs. $2-4$.

On the other hand, many methods for synthesizing anacardic acids $\mathbf{1}$ and $\mathbf{2}$ from a benzene skeletal structure have been reported, ${ }^{5-8)}$ and we have reported methods for synthesizing anacardic acids $\mathbf{1}$ and $\mathbf{2}$ utilizing an annelation reaction by means of the combination of two synthons, that is to say, via isoxazole derivertives ${ }^{9)}$ and 3-methoxyaclolein derivatives. $^{10)}$

However, no detailed studies on the synthesis of anacardic acids 3 and $\mathbf{4}$ which have two or three double bonds in the sidechain have been reported. Therefore, we have studied methods for the synthetic preparation of $\mathbf{3}$ and $\mathbf{4}$ according to our previous report. ${ }^{10)}$ First, we planned to synthesize anacardic acid 3 by performing a condensation and an annelation reaction with the 3-methoxyaclolein derivative (6) and dianion of ethyl acetoacetate after we composed the sidechain function (5) of anacardic acid 3, and after the part of the alcohol was changed into 3-methoxyaclolein derivative (6) (Chart 2). We tried various methods for the synthesis of 5 as shown in Chart 3, but it was difficult to prepare the desired compound.

Thus we attempted to induce an annelation reaction in advance of the synthesis of the sidechain function. Several 3methoxyacrolein derivatives were synthesized and investigated regarding the condensation and an annelation reaction to yield salicylate. In consequence, only 11-chloro-3methoxyaclorein was condensed with ethyl acetoacetate to give the condensed product, 6-(8-chlorooctyl)salicylate. As shown in Chart 4, 11-chloro-3-methoxyaclorein (11) was synthesized from 8-bromooctanol (7), that is to say, bromoalcohol was converted into 1-bromo-8-chlorooctane (8), and then the coupling reaction of the chloride with 3,3-diethoxy1 -propyne in the presence of butyllithium (BuLi) and hexa- methylphosphoric triamide (HMPA) in tetrahydrofuran (THF) gave the coupling product (9), in a $89.4 \%$ yield as a colorless oil, which was treated with $\mathrm{H}_{3} \mathrm{PO}_{4}$ and hydroquinone in dioxane to give the aldehyde (10) followed by $\mathrm{MeONa}$ in methanol to yield the 11-chloro-3-methoxy-2-undecenal (11). An annelation reaction with this aldehyde and ethyl acetoacetate proceeded to give the salycilate (12) in a $43.6 \%$ yield (Chart 4 ).

Next, we tried to synthesize anacardic acid $\mathbf{2}$ from $\mathbf{1 2}$ as the preliminary experiment in order to establish the synthetic method for preparation of anacardic acids 3 and 4. 6-(8Chlorooctyl)salicylate (12) was converted to aldehyde (15) through the iodide (14) after a protection of phenolic hydroxyl group (13). Kamikawa and co-workers synthesized ethyl 2-methoxy-6-[8(Z)-pentadecenyl]benzoate (17) which was derivative of anacardic acid 2 utilizing the Wittig reaction employing this aldehyde (15) and heptyltriphenylphosphonium iodide (16). ${ }^{5)}$ According to the above method after it proceeded through the Witting reaction with $\mathbf{1 5}$ and 16, we obtained the product (17) in a $76.4 \%$ yield. The protecting groups were removed by successive treatments with $\mathrm{BBr}_{3}$ in $\mathrm{CH}_{2} \mathrm{Cl}_{2}$ and $10 \% \mathrm{NaOH}$ in ethanol to give the anacardic acid
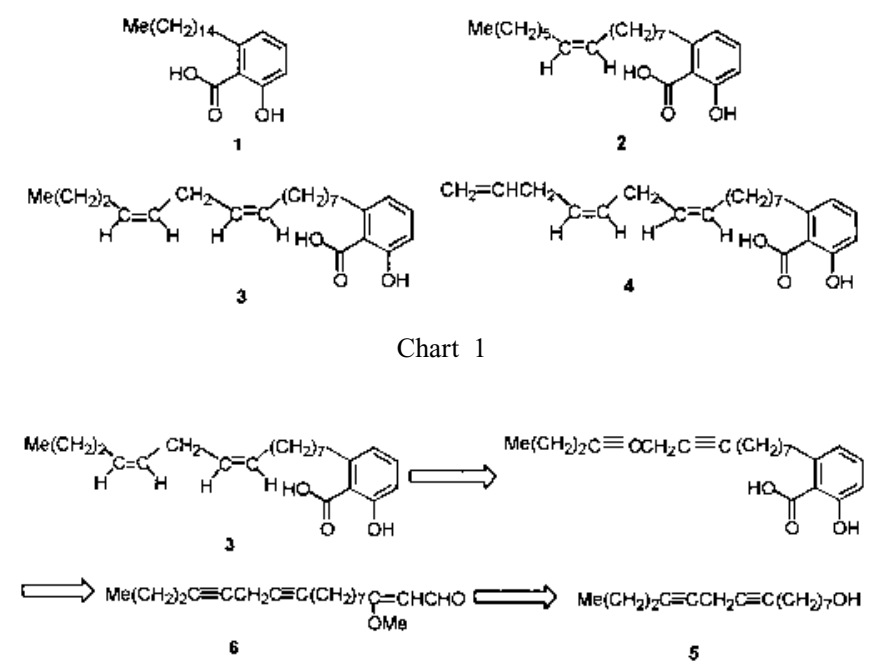

Chart 2

* To whom correspondence should be addressed. e-mail: ms@ac.shoyaku.ac.jp

(C) 2001 Pharmaceutical Society of Japan 
2 in a $62.2 \%$ yield from 17 (Chart 5).

Consequently, it was anticipated that anacardic acids 3 and 4 were synthesized from aldehyde (15). Therefore, we tried to synthesize the sidechain functions of anacardic acid $\mathbf{3}$ and 4 from 3-butynol. The coupling reaction of 3-butynol (19) with alkyl iodide in the presence of BuLi and HMPA in THF gave the coupling products (20: $70.6 \%, 24: 90.4 \%)$, which were reduced with Lindlar catalyst in quinoline and hexane to yield the cis-alkenyl alcohols (21: $65.1 \%, \mathbf{2 5}: \mathbf{7 5 . 3 \% )}$ as colorless oils. These cis-alkenyl alcohols were treated with iodine in the presence of $\mathrm{PPh}_{3}$ and imidazole to give the iodides (22: $65.5 \%, 26: 71.9 \%)$ as colorless oils, which were converted to derivatives of triphenylphosphonium iodides (23: 95.5\%, 27: 99.3\%) with $\mathrm{PPh}_{3}$ in acetonitrile. Finally, The Wittig reaction with these triphenylphosphonium iodides $(\mathbf{2 3}, \mathbf{2 7})$ and aldehyde $(\mathbf{1 5})$ in the presence of BuLi gave the
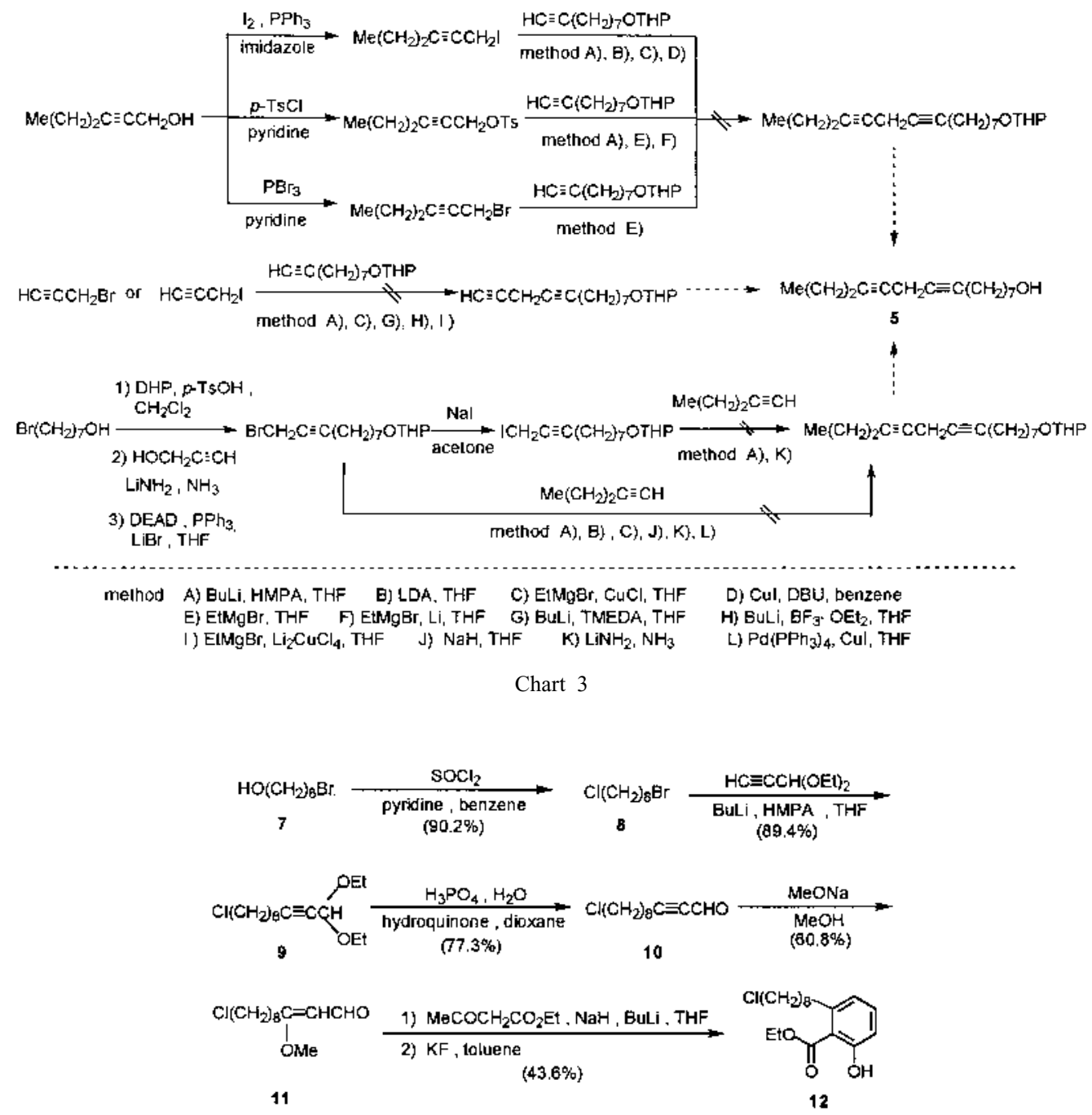

Chart 4
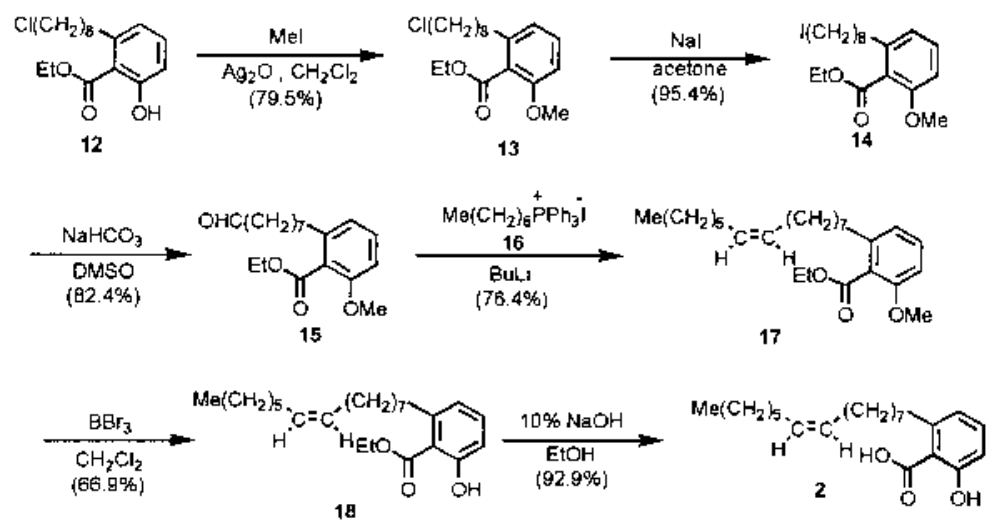

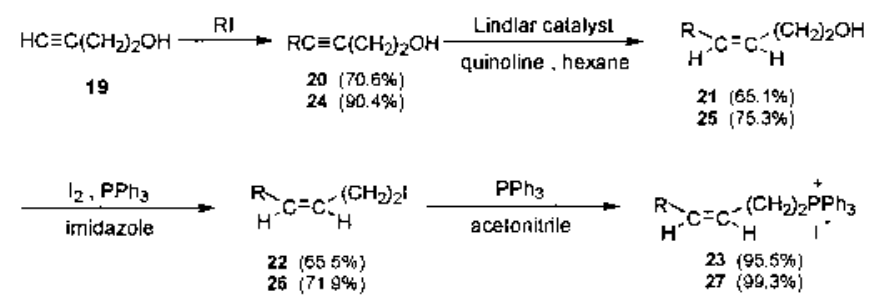

$\left.20,21,22,23 ; R=\mathrm{Me}_{2} \mathrm{CH}_{2}\right)_{2}-\quad 24,25,28,27 ; \mathrm{R}=\mathrm{H}_{2} \mathrm{C}=\mathrm{CHCH}_{2}-$

Chart 6

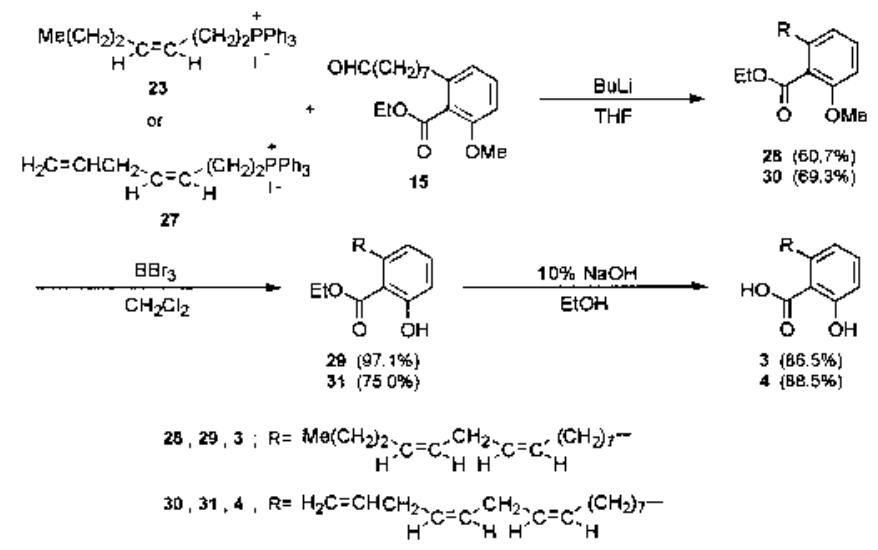

Chart 7

methoxybenzoates $(\mathbf{2 8}: 60.7 \%, \mathbf{3 0}: 69.3 \%)$, and then treatments of these methoxybenzoates $(\mathbf{2 8}, \mathbf{3 0})$ with $\mathrm{BBr}_{3}$ in $\mathrm{CH}_{2} \mathrm{Cl}_{2}$ and $10 \% \mathrm{NaOH}$ in ethanol gave anacardic acids 3 and 4 in $84.0 \%(\mathbf{2 8} \rightarrow \mathbf{3})$ and $66.4 \%(\mathbf{3 0} \rightarrow \mathbf{4})$ yields (Charts 6 , 7). All physical data for synthetic products 3 and $\mathbf{4}$ showed structures for $\mathbf{3}$ and $\mathbf{4}$.

\section{Experimental}

All melting points were determined on a Yanagimoto melting point apparatus. IR spectra were recorded with Hitachi 260-10 spectrometer and JEOL A-202 spectrometer. The ${ }^{1} \mathrm{H}$ - and ${ }^{13} \mathrm{C}-\mathrm{NMR}$ spectra were measured on a JEOL JNM-EX90 and JEOL JNM- $\alpha 500$ spectrometer in $\mathrm{CDCl}_{3}$ containing tetramethylsilane (TMS) as an internal standard. The mass spectra were recorded on a JEOL JMS-D 300. Waco-gel was used for column chromatography.

1-Bromo-8-chlorooctane (8) A solution of 8-bromooctanol (198.6 mg) in benzene $(2 \mathrm{ml})$ and pyridine $(126.6 \mathrm{mg})$ was heated to $60^{\circ} \mathrm{C}$ under a nitrogen atmosphere. After thionyl chloride $(116 \mu 1)$ was added dropwise with stirring, the mixture was stirred at $75^{\circ} \mathrm{C}$ for $7 \mathrm{~h}$. The reaction mixture was treated with cold water and extracted with AcOEt. The organic layer was washed with saturated $\mathrm{NaHCO}_{3}$ and $\mathrm{NaCl}$ solution, dried $\left(\mathrm{MgSO}_{4}\right)$ and concentrated. The residue was subjected to silica gel chromatography (hexane : $\mathrm{CHCl}_{3}=4: 1$ ) to yield $195.3 \mathrm{mg}(90.2 \%)$ of 8 as a colorless oil. ${ }^{1} \mathrm{H}$ NMR $\left(\mathrm{CDCl}_{3}\right) \delta: 1.34-1.48(8 \mathrm{H}, \mathrm{m}), 1.70-1.86(4 \mathrm{H}, \mathrm{m}), 3.42(2 \mathrm{H}, \mathrm{t}$, $J=6.7 \mathrm{~Hz}), 3.54(2 \mathrm{H}, \mathrm{t}, J=6.6 \mathrm{~Hz})$.

11-Chloro-1,1-Diethoxy-2-undecyne (9) BuLi in hexane (1.66 M, 18.6 $\mathrm{ml})$ and HMPA $(2.44 \mathrm{ml})$ were successively added dropwise to a stirred solution of propiolaldehyde diethylacetal $(1.79 \mathrm{~g})$ in $\mathrm{THF}(30 \mathrm{ml})$ at $0{ }^{\circ} \mathrm{C}$ under a nitrogen atmosphere. After $30 \mathrm{~min}$, a solution of $8(1.57 \mathrm{~g})$ in THF $(5 \mathrm{ml})$ was added to the reaction mixture and the whole was stirred at $0{ }^{\circ} \mathrm{C}$ for $1 \mathrm{~h}$ under a nitrogen. And then the reaction mixture was quenched with saturated $\mathrm{NH}_{4} \mathrm{Cl}$ solution, extracted with AcOEt, washed with saturated $\mathrm{NaCl}$ solution, dried $\left(\mathrm{MgSO}_{4}\right)$ and concentrated. The residue was subjected to silica gel chromatography (hexane : $\mathrm{CHCl}_{3}=3: 2$ ) to yield $1.72 \mathrm{~g}(89.4 \%)$ of 9 as a colorless oil. IR $v_{\max }^{\mathrm{KBr}} \mathrm{cm}^{-1}: 2242 .{ }^{1} \mathrm{H}-\mathrm{NMR}\left(\mathrm{CDCl}_{3}\right) \delta: 1.24(6 \mathrm{H}, \mathrm{t}$, $J=7.0 \mathrm{~Hz}), 1.28-1.56(10 \mathrm{H}, \mathrm{m}), 1.77(2 \mathrm{H}, \mathrm{m}), 2.24(2 \mathrm{H}, \mathrm{dt}, J=7.1,1.7$ $\mathrm{Hz}), 3.57(4 \mathrm{H}, \mathrm{m}), 3.74(2 \mathrm{H}, \mathrm{m}), 5.26(1 \mathrm{H}, \mathrm{t}, J=1.7 \mathrm{~Hz})$. Chemical ionization (CI)-MS $m / z: 273,275\left(\mathrm{M}^{+}+1\right)$.
11-Chloro-2-undecynal (10) $\quad \mathrm{H}_{2} \mathrm{O}(48 \mathrm{ml}), 85 \% \mathrm{H}_{3} \mathrm{PO}_{4}(26 \mathrm{ml})$ and hydroquinone $(910 \mathrm{mg})$ was added to a solutoin of $9(2.29 \mathrm{~g})$ in dioxane $(150 \mathrm{ml})$ and the mixture was refluxed at $100^{\circ} \mathrm{C}$ for $4.5 \mathrm{~h}$. The reaction mixture was concentrated under vacuum. An aqueous solution of the residue was then extracted with diethyl ether. The organic layer was washed with saturated $\mathrm{NaHCO}_{3}$ solution, dried $\left(\mathrm{MgSO}_{4}\right)$ and concentrated. The residue was subjected to silica gel chromatography (hexane: $\mathrm{CHCl}_{3}=1: 1$ ) to yield $1.29 \mathrm{~g}(77.3 \%)$ of $\mathbf{1 0}$ as a colorless oil. IR $v_{\max }^{\mathrm{KBr}} \mathrm{cm}^{-1}: 2238,2202,1710$, 1673. ${ }^{1} \mathrm{H}-\mathrm{NMR}\left(\mathrm{CDCl}_{3}\right) \delta: 1.25-1.80(12 \mathrm{H}, \mathrm{m}), 2.39(2 \mathrm{H}, \mathrm{t}, J=7.0 \mathrm{~Hz})$, $3.54(2 \mathrm{H}, \mathrm{t}, J=6.7 \mathrm{~Hz}), 9.18(1 \mathrm{H}, \mathrm{s})$. CI-MS $m / z: 201,203\left(\mathrm{M}^{+}+1\right)$.

11-Chloro-3-methoxy-2-undecenal (11) Sodium methoxide $(1.0 \mathrm{M}$, $1.8 \mathrm{ml})$ was added to a solutoin of $\mathbf{1 0}(301.5 \mathrm{mg})$ in anhydrous methanol $(10 \mathrm{ml})$ and the mixture was stirred at room temperature for $1.5 \mathrm{~h}$. The reaction mixture was treated with water, and acidified with $10 \% \mathrm{HCl}$ and then extracted with diethyl ether. The organic layer was washed with saturated $\mathrm{NaCl}$ solution, dried $\left(\mathrm{MgSO}_{4}\right)$ and concentrated. The residue was subjected to silica gel chromatography (hexane: $\mathrm{AcOEt}=4: 1$ ) to yield $212.6 \mathrm{mg}$ $(60.8 \%)$ of 11 as a colorless oil. IR $v_{\max }^{\mathrm{KBr}} \mathrm{cm}^{-1}: 1660,1607 .{ }^{1} \mathrm{H}-\mathrm{NMR}$ $\left(\mathrm{CDCl}_{3}\right) \delta: 1.25-1.80(12 \mathrm{H}, \mathrm{m}), 2.60(2 \mathrm{H}, \mathrm{t}, J=7.4 \mathrm{~Hz}), 3.53(2 \mathrm{H}, \mathrm{t}, J=$ $6.5 \mathrm{~Hz}), 3.68(3 \mathrm{H}, \mathrm{s}), 5.38(1 \mathrm{H}, \mathrm{d}, J=7.8 \mathrm{~Hz}), 9.80(1 \mathrm{H}, \mathrm{d}, J=7.8 \mathrm{~Hz})$. CIMS $m / z: 233,235\left(\mathrm{M}^{+}+1\right)$.

Ethyl 6-(8-Chlorooctyl)salicylate (12) A solution of ethyl acetoacetate $(1.67 \mathrm{~g})$ in THF $(20 \mathrm{ml})$ was treated with $\mathrm{NaH}(362 \mathrm{mg})$ and stirred at $0{ }^{\circ} \mathrm{C}$ for $10 \mathrm{~min}$ under nitrogen, BuLi $(1.65 \mathrm{M}, 9.15 \mathrm{ml})$ in hexane was then added dropwise with stirring. After the reaction mixture was cooled to $-30^{\circ} \mathrm{C}, \mathbf{1 1}$ $(167.1 \mathrm{mg})$ in THF $(1 \mathrm{ml})$ was added to the reaction mixture, and the whole was stirred at $-30^{\circ} \mathrm{C}$ for $3.5 \mathrm{~h}$ under a nitrogen. The reaction mixture was quenched with saturated $\mathrm{NH}_{4} \mathrm{Cl}$, and acidified with $10 \% \mathrm{HCl}$ and extracted with AcOEt. The organic layer was washed with saturated $\mathrm{NaCl}$ solution, dried $\left(\mathrm{MgSO}_{4}\right)$ and concentrated. A solution of the residue in toluene $(30 \mathrm{ml})$ and $\mathrm{KF}(836.6 \mathrm{mg})$ was refluxed for $15 \mathrm{~h}$. The reaction mixture was concentrated under a vacuum. A solution of the residue in $\mathrm{H}_{2} \mathrm{O}$ was extracted with $\mathrm{CHCl}_{3}$. The organic layer was washed with saturated $\mathrm{NaCl}$ solution, dried $\left(\mathrm{MgSO}_{4}\right)$ and concentrated. The residue was subjected to silica gel chromatography (hexane : $\mathrm{AcOEt}=9: 1)$ to yield $98.2 \mathrm{mg}(43.6 \%)$ of $\mathbf{1 2}$ as a colorless oil. IR $v_{\max }^{\mathrm{KBr}} \mathrm{cm}^{-1}: 1659,1609,1576 .{ }^{1} \mathrm{H}-\mathrm{NMR}\left(\mathrm{CDCl}_{3}\right) \delta$ : $1.25-1.80(12 \mathrm{H}, \mathrm{m}), 1.44(3 \mathrm{H}, \mathrm{t}, J=7.1 \mathrm{~Hz}), 2.90(2 \mathrm{H}, \mathrm{dd}, J=7.6,6.1 \mathrm{~Hz})$, $3.54(2 \mathrm{H}, \mathrm{t}, J=6.7 \mathrm{~Hz}), 4.44(2 \mathrm{H}, \mathrm{q}, J=7.1 \mathrm{~Hz}), 6.71(1 \mathrm{H}, \mathrm{dd}, J=7.3,1.2$ $\mathrm{Hz}), 6.84(1 \mathrm{H}, \mathrm{dd}, J=8.2,1.2 \mathrm{~Hz}), 7.29(1 \mathrm{H}, \mathrm{dd}, J=8.2,7.3 \mathrm{~Hz}), 11.23(1 \mathrm{H}$, s). High-MS $m / z$ : $312.1551,314.1505$ (Calcd for $\mathrm{C}_{17} \mathrm{H}_{25} \mathrm{ClO}_{3}: 312.1546$, 314.1463).

Ethyl 6-(8-Chlorooctyl)-2-methoxybenzoate (13) $\quad \mathrm{Ag}_{2} \mathrm{O}(46.4 \mathrm{mg})$ and MeI $(249 \mu \mathrm{l})$ was added to a solution of $\mathbf{1 2}(15.9 \mathrm{mg})$ in $\mathrm{CH}_{2} \mathrm{Cl}_{2}(2 \mathrm{ml})$ and the mixture was stirred at room temperature for $24 \mathrm{~h}$. After filtration, the reaction mixture was concentrated under a vacuum. The residue was subjected to silica gel chromatography (hexane: $\mathrm{AcOEt}=4: 1$ ) to yield $13.0 \mathrm{mg}$ $(79.5 \%)$ of 13 as a colorless oil. IR $v_{\max }^{\mathrm{KBr}} \mathrm{cm}^{-1}: 1730,1584 .{ }^{1} \mathrm{H}-\mathrm{NMR}$ $\left(\mathrm{CDCl}_{3}\right) \delta: 1.30-1.70(12 \mathrm{H}, \mathrm{m}), 1.37(3 \mathrm{H}, \mathrm{t}, J=7.2 \mathrm{~Hz}), 2.55(2 \mathrm{H}, \mathrm{t}, J=$ $7.4 \mathrm{~Hz}), 3.52(2 \mathrm{H}, \mathrm{t}, J=6.5 \mathrm{~Hz}), 3.81(3 \mathrm{H}, \mathrm{s}), 4.39(2 \mathrm{H}, \mathrm{q}, J=7.2 \mathrm{~Hz}), 6.75$ $(1 \mathrm{H}, \mathrm{d}, J=8.1 \mathrm{~Hz}), 6.80(1 \mathrm{H}, \mathrm{d}, J=7.2 \mathrm{~Hz}), 7.26(1 \mathrm{H}, \mathrm{dd}, J=7.2,8.1 \mathrm{~Hz})$. High-MS $m / z$ : 326.1647, 328.1688 (Calcd for $\mathrm{C}_{18} \mathrm{H}_{27} \mathrm{ClO}_{3}: 326.1547$, $328.1620)$.

Ethyl 6-(8-Iodooctyl)-2-methoxybenzoate (14) A solution of 13 $(9.5 \mathrm{mg})$ and $\mathrm{NaI}(45 \mathrm{mg})$ in acetone was refluxed for $24 \mathrm{~h}$. The reaction mixture was quenched with cold water, extracted with AcOEt. The organic layer was washed with saturated $\mathrm{NaCl}$ solution, dried and concentrated. The residue was subjected to silica gel chromatography (hexane: $\mathrm{AcOEt}=4: 1$ ) to yield $11.6 \mathrm{mg}(95.4 \%)$ of $\mathbf{1 4}$ as a colorless oil. IR $v_{\max }^{\mathrm{KBr}} \mathrm{cm}^{-1}: 1732,1585$. ${ }^{1} \mathrm{H}-\mathrm{NMR}\left(\mathrm{CDCl}_{3}\right) \delta: 1.29-1.38(8 \mathrm{H}, \mathrm{m}), 1.38(3 \mathrm{H}, \mathrm{t}, J=7.1 \mathrm{~Hz}), 1.59(2 \mathrm{H}$, $\mathrm{m}), 1.81(2 \mathrm{H}$, quin, $J=7.0 \mathrm{~Hz}), 2.55(2 \mathrm{H}, \mathrm{t}, J=7.9 \mathrm{~Hz}), 3.18(2 \mathrm{H}, \mathrm{t}, J=$ $7.0 \mathrm{~Hz}), 3.81(3 \mathrm{H}, \mathrm{s}), 4.39(2 \mathrm{H}, \mathrm{q}, J=7.1 \mathrm{~Hz}), 6.76(1 \mathrm{H}, \mathrm{d}, J=7.8 \mathrm{~Hz}), 6.81$ $(1 \mathrm{H}, \mathrm{d}, J=7.8 \mathrm{~Hz}), 7.26(1 \mathrm{H}, \mathrm{t}, J=7.8 \mathrm{~Hz}$ ). High-MS $m / z: 418.1032$ (Calcd for $\left.\mathrm{C}_{18} \mathrm{H}_{27} \mathrm{IO}_{3}: 418.1008\right)$.

Ethyl 6-(7-Formylheptyl)-2-methoxybenzoate (15) 14 and $\mathrm{NaHCO}_{3}$ $(8.4 \mathrm{mg})$ were dissolved with dimethyl sulfoxide (DMSO) $(2 \mathrm{ml})$, and the whole was stirred at $90^{\circ} \mathrm{C}$ for $11 \mathrm{~h}$ under nitrogen. The reaction mixture was treated with cold water and extracted with AcOEt. The organic layer was washed with saturated $\mathrm{NaCl}$ solution, dried $\left(\mathrm{MgSO}_{4}\right)$ and concentrated. The residue was subjected to silica gel chromatography (hexane: $\mathrm{AcOEt}=4: 1$ ) to yield $12.3 \mathrm{mg}(82.4 \%)$ of $\mathbf{1 5}$ as a colorless oil. IR $v_{\max }^{\mathrm{KBr}} \mathrm{cm}^{-1}: 1730,1580$. ${ }^{1} \mathrm{H}-\mathrm{NMR}\left(\mathrm{CDCl}_{3}\right) \delta: 1.26-1.64(10 \mathrm{H}, \mathrm{m}), 1.37(3 \mathrm{H}, \mathrm{t}, J=7.0 \mathrm{~Hz}), 2.41$ $(2 \mathrm{H}, \mathrm{dt}, J=7.3,1.8 \mathrm{~Hz}), 2.55(2 \mathrm{H}, \mathrm{t}, J=7.8 \mathrm{~Hz}), 3.81(3 \mathrm{H}, \mathrm{s}), 4.39(2 \mathrm{H}, \mathrm{q}$, $J=7.1 \mathrm{~Hz}), 6.76(1 \mathrm{H}, \mathrm{d}, J=7.8 \mathrm{~Hz}), 6.80(1 \mathrm{H}, \mathrm{d}, J=7.8 \mathrm{~Hz}), 7.26(1 \mathrm{H}, \mathrm{t}$, $J=7.8 \mathrm{~Hz}), 9.75(1 \mathrm{H}, \mathrm{t}, J=1.8 \mathrm{~Hz})$. High-MS $m / z: 306.1865$ (Calcd for 
$\mathrm{C}_{18} \mathrm{H}_{26} \mathrm{O}_{4}: 306.1830$ ).

Hepthyltriphenylphosphonium Iodide (16) $\mathrm{PPh}_{3}(1.73 \mathrm{~g})$ was added to a solution of 1-iodoheptane $(995 \mathrm{mg})$ in acetonitrile $(30 \mathrm{ml})$, and the whole was stirred at $90^{\circ} \mathrm{C}$ for $24 \mathrm{~h}$ under nitrogen. The mixture was allowed to stand at room temperature for $18 \mathrm{~h}$ with stirring. After filtration, the solid obtained was washed with THF to yield $1.92 \mathrm{~g}(\mathbf{9 7 . 1 \% )}$ of $\mathbf{1 6}$ as a colorless solid. This compound was employed for next reaction without purification. ${ }^{1} \mathrm{H}-\mathrm{NMR}\left(\mathrm{CDCl}_{3}\right) \delta: 0.82(3 \mathrm{H}, \mathrm{t}, J=5.6 \mathrm{~Hz}), 1.10-1.80(10 \mathrm{H}, \mathrm{m}), 3.45-$ $3.85(2 \mathrm{H}, \mathrm{m}), 7.66-7.96(15 \mathrm{H}, \mathrm{m})$.

Ethyl 2-Methoxy-6-[8(Z)-pentadecenyl]benzoate (17) BuLi (1.58 M, $159 \mu \mathrm{l})$ was successively added to a stirred solution of $\mathbf{1 6}(115 \mathrm{mg})$ in THF $(2 \mathrm{ml})$ at room temperature under a nitrogen. After $1 \mathrm{~h}$, a solution of $\mathbf{1 5}$ $(14.4 \mathrm{mg})$ in THF was added to the reaction mixture and the whole was stirred at $0{ }^{\circ} \mathrm{C}$ for $30 \mathrm{~min}$ under a nitrogen. And then the reaction mixture was quenched with saturated $\mathrm{NH}_{4} \mathrm{Cl}$, extracted with AcOEt. The organic layer was washed with saturated $\mathrm{NaCl}$ solution, dried $\left(\mathrm{MgSO}_{4}\right)$ and concentrated. The residue was subjected to silica gel chromatography (hexane: AcOEt $=9: 1)$ to yield $13.9 \mathrm{mg}(76.4 \%)$ of $\mathbf{1 7}$ as a colorless oil. IR $v_{\max }^{\mathrm{KBr}} \mathrm{cm}^{-1}: 1730,1590 .{ }^{1} \mathrm{H}-\mathrm{NMR}\left(\mathrm{CDCl}_{3}\right) \delta: 0.88(3 \mathrm{H}, \mathrm{t}, J=6.7 \mathrm{~Hz}), 1.20-$ $1.40(18 \mathrm{H}, \mathrm{m}), 1.37(3 \mathrm{H}, \mathrm{t}, J=7.2 \mathrm{~Hz}), 1.99(4 \mathrm{H}, \mathrm{t}, J=6.0 \mathrm{~Hz}), 2.55(2 \mathrm{H}, \mathrm{t}$, $J=7.9 \mathrm{~Hz}), 3.81(3 \mathrm{H}, \mathrm{s}), 4.39(2 \mathrm{H}, \mathrm{q}, J=7.2 \mathrm{~Hz}), 5.35(2 \mathrm{H}, \mathrm{t}, J=5.5 \mathrm{~Hz}), 6.75$ $(1 \mathrm{H}, \mathrm{d}, J=7.8 \mathrm{~Hz}), 6.81(1 \mathrm{H}, \mathrm{t}, J=7.8 \mathrm{~Hz}), 7.25(1 \mathrm{H}, \mathrm{t}, J=7.8 \mathrm{~Hz})$. High-MS $m / z: 388.1865$ (Calcd for $\mathrm{C}_{25} \mathrm{H}_{40} \mathrm{O}_{3}: 388.1830$ ).

Ethyl 6-[8(Z)-Pentadecenyl]salycylate (18) A solution of $\mathbf{1 7}(13.2 \mathrm{mg})$ in absolute $\mathrm{CH}_{2} \mathrm{Cl}_{2}$ was added to a solution of $\mathrm{BBr}_{3}(6.4 \mu \mathrm{l})$ in anhydrous $\mathrm{CH}_{2} \mathrm{Cl}_{2}$ at $0{ }^{\circ} \mathrm{C}$ under a nitrogen, and the whole was stirred at room temperature for $15 \mathrm{~min}$ under a nitrogen. And then the reaction mixture was quenched with cold water and extracted with $\mathrm{CH}_{2} \mathrm{Cl}_{2}$. The organic layer was washed with saturated $\mathrm{NaCl}$ solution, dried $\left(\mathrm{MgSO}_{4}\right)$ and concentrated. The residue was subjected to silica gel chromatography (hexane : $\mathrm{AcOEt}=9: 1$ ) to yield $8.5 \mathrm{mg}(66.9 \%)$ of $\mathbf{1 8}$ as a colorless oil. IR $v_{\max }^{\mathrm{KBr}} \mathrm{cm}^{-1}: 3100,1660$, 1608. ${ }^{1} \mathrm{H}-\mathrm{NMR}\left(\mathrm{CDCl}_{3}\right) \delta: 0.87(3 \mathrm{H}, \mathrm{t}, J=5.7 \mathrm{~Hz}), 1.25-1.60(21 \mathrm{H}, \mathrm{m})$, $1.98(4 \mathrm{H}, \mathrm{m}), 2.91(2 \mathrm{H}, \mathrm{t}, J=7.4 \mathrm{~Hz}), 4.43(2 \mathrm{H}, \mathrm{q}, J=7.1 \mathrm{~Hz}), 5.34(2 \mathrm{H}, \mathrm{m})$, $6.71(1 \mathrm{H}, \mathrm{dd}, J=8.3,1.3 \mathrm{~Hz}), 6.81(1 \mathrm{H}, \mathrm{dd}, J=7.4,1.3 \mathrm{~Hz}), 7.28(1 \mathrm{H}, \mathrm{dd}$, $J=8.3,7.4 \mathrm{~Hz}), 11.20(1 \mathrm{H}, \mathrm{s})$. Low MS $m / z: 374\left(\mathrm{M}^{+}\right)$, High MS $m / z$ Calcd for $\mathrm{C}_{24} \mathrm{H}_{38} \mathrm{O}_{3}\left(\mathrm{M}^{+}\right)$: 374.2821 . Found: 374.2827 .

6-(8-Pentadecenyl)salicylic Acid (2) A solution of $18(10.2 \mathrm{mg})$ in EtOH and $10 \% \mathrm{NaOH}(1 \mathrm{ml})$ were refluxd for $2 \mathrm{~h}$. A solution of the reaction mixture was acidified with $10 \% \mathrm{HCl}$ and then extracted with hexane. The organic layer was washed with saturated $\mathrm{NaCl}$ solution., dried and concentrated. The residue was subjected to silica gel chromatography (hexane: $\mathrm{AcOEt}=1: 2$ ). The eluate fraction was recrystalized from hexane to yield $9.2 \mathrm{mg}(92.9 \%)$ of 2 as colorless crystals, mp $45-48^{\circ} \mathrm{C}$. IR $v_{\max }^{\mathrm{KBr}} \mathrm{cm}^{-1}: 2930,2850,1650,1600 .{ }^{1} \mathrm{H}-\mathrm{NMR}\left(\mathrm{CDCl}_{3}\right) \delta: 0.88(3 \mathrm{H}, \mathrm{t}$, $J=5.7 \mathrm{~Hz}), 1.25-1.60(18 \mathrm{H}, \mathrm{m}), 1.97(4 \mathrm{H}, \mathrm{m}), 2.93(2 \mathrm{H}, \mathrm{t}, J=7.4 \mathrm{~Hz}), 5.35$ $(2 \mathrm{H}, \mathrm{m}), 6.71(1 \mathrm{H}, \mathrm{dd}, J=8.3,1.3 \mathrm{~Hz}), 6.81(1 \mathrm{H}, \mathrm{dd}, J=7.4,1.3 \mathrm{~Hz}), 7.28$ $(1 \mathrm{H}, \mathrm{dd}, J=8.3,7.4 \mathrm{~Hz})$. Low MS $m / z: 346\left(\mathrm{M}^{+}\right)$. Anal. Calcd for $\mathrm{C}_{22} \mathrm{H}_{34} \mathrm{O}_{3}$ : C, 76.25; H, 9.90. Found: C, 76.08; H, 10.06 .

3-Heptynol (20) Dihydropyrane (DHP) $(4.88 \mathrm{ml})$ and $p$-toluenesulfonic acid $(\mathrm{TsOH})(120 \mathrm{mg})$ were added to a solution of $19(3.6 \mathrm{~g})$ in $\mathrm{CH}_{2} \mathrm{Cl}_{2}$ and the mixture was stirred at room temperature for $3 \mathrm{~h}$. The reaction mixture was quenched with cold water and saturated $\mathrm{NaHCO}_{3}$ solution, and extructed with $\mathrm{CH}_{2} \mathrm{Cl}_{2}$. The organic layer was washed with saturated $\mathrm{NaCl}$ solution, dried and concentrated. The residue was subjected to silica gel chromatography (hexane: $\mathrm{AcOEt}=4: 1$ ) to yield $9.63 \mathrm{~g}(95.2 \%)$ of 1-[2-(tetrahydropyranyl)oxy]-3-butyne as a colorless oil. [IR $v_{\max }^{\mathrm{KBr}} \mathrm{cm}^{-1}: 3270 .{ }^{1} \mathrm{H}-\mathrm{NMR}$ $\left(\mathrm{CDCl}_{3}\right) \delta: 1.40-1.81(6 \mathrm{H}, \mathrm{m}), 1.97(1 \mathrm{H}, \mathrm{t}, J=2.6 \mathrm{~Hz}), 2.49(2 \mathrm{H}, \mathrm{dd}$, $J=7.0,2.6 \mathrm{~Hz}), 3.44-4.00(4 \mathrm{H}, \mathrm{m}), 4.64(1 \mathrm{H}, \mathrm{brs})$. CI-MS $\mathrm{m} / \mathrm{z}: 155$ $\left(\mathrm{M}^{+}+1\right)$.] BuLi $(1.58 \mathrm{M}, 9.45 \mathrm{ml})$ and HMPA $(2.7 \mathrm{ml})$ were successively added to a solution of 1-[2-(tetrahydropyranyl)oxy]-3-butyne (2.0 g) in THF $(10 \mathrm{ml})$ at $0{ }^{\circ} \mathrm{C}$ with stirring. After a solution of propyl iodide $(3.79 \mathrm{~g})$ in THF was added to this solution, the whole was stirred at $0^{\circ} \mathrm{C}$ for $1 \mathrm{~h}$. The mixture was then allowed to stand at room temperature for $1 \mathrm{~h}$. The reaction mixture was treated with saturated $\mathrm{NH}_{4} \mathrm{Cl}$ solution and extracted with AcOEt. The organic layer was washed with saturated $\mathrm{NaCl}$ solution, dried and concentrated. The residue was subjected to silica gel chromatography (hexane : $\mathrm{AcOEt}=9: 1)$ to yield $2.07 \mathrm{~g}(81.4 \%)$ of 1-[2-(tetrahydropyranyl)oxy]-3-heptyne as a colorless oil. [IR $v_{\max }^{\mathrm{KBr}} \mathrm{cm}^{-1}: 2250 .{ }^{1} \mathrm{H}-\mathrm{NMR}\left(\mathrm{CDCl}_{3}\right) \delta$ : $0.97(3 \mathrm{H}, \mathrm{t}, J=7.5 \mathrm{~Hz}), 1.43-1.86(6 \mathrm{H}, \mathrm{m}), 2.12(2 \mathrm{H}, \mathrm{dd}, J=7.0,2.4 \mathrm{~Hz})$, $2.46(2 \mathrm{H}, \mathrm{dd}, J=7.0,2.4 \mathrm{~Hz}), 3.47-3.57(2 \mathrm{H}, \mathrm{m}), 3.75-3.93(2 \mathrm{H}, \mathrm{m}), 4.65$ $(1 \mathrm{H}, \mathrm{t}, J=3.6 \mathrm{~Hz})$. CI-MS $m / z: 197\left(\mathrm{M}^{+}+1\right)$. A solution of 1-[2-(tetrahydropyranyl)oxy]-3-heptyne $(597 \mathrm{mg})$ in anhydrous $\mathrm{EeOH}(20 \mathrm{ml})$ and pyridinium paratoluenesulfonic acid (PPTS) $(153.3 \mathrm{mg})$ was stirred at $55^{\circ} \mathrm{C}$ for $3 \mathrm{~h}$. The reaction mixture was concentrated under vacuum. The residue was subjected to silica gel chromatography (hexane: $\mathrm{AcOEt}=4: 1$ ) to yield $311.2 \mathrm{mg}(91.1 \%)$ of 20 as a colorless oil. IR $v_{\max }^{\mathrm{KBr}} \mathrm{cm}^{-1}: 3362,2230 .{ }^{1} \mathrm{H}-$ $\operatorname{NMR}\left(\mathrm{CDCl}_{3}\right) \delta: 0.97(3 \mathrm{H}, \mathrm{t}, J=7.3 \mathrm{~Hz}), 1.45-1.59(2 \mathrm{H}, \mathrm{m}), 1.87(1 \mathrm{H}, \mathrm{br} \mathrm{s})$, $2.15(2 \mathrm{H}, \mathrm{dd}, J=7.0,2.4 \mathrm{~Hz}), 2.44(2 \mathrm{H}, \mathrm{dd}, J=6.3,2.4 \mathrm{~Hz}), 3.68(2 \mathrm{H}, \mathrm{br} \mathrm{s})$.

3(Z)-Heptenol (21) A mixture of Lindlar's catalyst $\left(\mathrm{Pd} \mathrm{CaCO}_{3}, 40 \mathrm{mg}\right)$, quinoline $(10 \mu \mathrm{l})$ and $20(193.5 \mathrm{mg})$ in hexane $(4.0 \mathrm{ml})$ was stirred at room temperature for $16 \mathrm{~h}$ under $\mathrm{H}_{2}$. After the mixture was filtered, $10 \% \mathrm{HCl}$ was added to the filter liquid and extracted with ether. The organic layer was washed with saturated $\mathrm{NaCl}$ solution, dried and concentrated. The residue was subjected to silica gel chromatography (hexane : $\mathrm{AcOEt}=2: 1$ ) to yield $128.3 \mathrm{mg}(65.1 \%)$ of 21 as a colorless oil. IR $v_{\max }^{\mathrm{KBr}} \mathrm{cm}^{-1}: 3350,1660 .{ }^{1} \mathrm{H}-$ NMR $\left(\mathrm{CDCl}_{3}\right) \delta: 0.90(3 \mathrm{H}, \mathrm{t}, J=7.1 \mathrm{~Hz}), 1.19-1.52(2 \mathrm{H}, \mathrm{m}), 1.56(1 \mathrm{H}$, br s), $2.05(2 \mathrm{H}, \mathrm{q}, J=6.5 \mathrm{~Hz}), 2.33(2 \mathrm{H}, \mathrm{q}, J=6.5 \mathrm{~Hz}), 3.64(2 \mathrm{H}, \mathrm{t}$, $J=7.2 \mathrm{~Hz}), 5.34-5.64(2 \mathrm{H}, \mathrm{m})$.

1-Iodo-3(Z)-heptene (22) A solution of $\mathrm{PPh}_{3}(378 \mathrm{mg})$ and imidazole $(98 \mathrm{mg})$ in mixture of diethyl ether and acetonitrile $(3: 1,35 \mathrm{ml})$ was stirred at $0{ }^{\circ} \mathrm{C}$ for $10 \mathrm{~min}$ and then iodine $(366 \mathrm{mg})$ was added to this solution. The whole was stirred at $0{ }^{\circ} \mathrm{C}$ for $15 \mathrm{~min}$. A solution of $21(54.4 \mathrm{mg})$ in mixture of diethyl ether and acetonitrile $(3: 1,1 \mathrm{ml})$ was added to this solution with stirring at $0^{\circ} \mathrm{C}$. The mixture was then allowed to stand at room temperature for $1 \mathrm{~h}$. The reaction mixture was treated with saturated $\mathrm{NaHCO}_{3}$ solution and extracted with ether. The organic layer was washed with saturated $\mathrm{NaCl}$ solution, dried and concentrated. The residue was subjected to silica gel chromatography (hexane : $\mathrm{AcOEt}=9: 1)$ to yield $70.4 \mathrm{mg}(65.5 \%)$ of 22 as a colorless oil. IR $v_{\max }^{\mathrm{KBr}} \mathrm{cm}^{-1}: 1660 .{ }^{1} \mathrm{H}-\mathrm{NMR}\left(\mathrm{CDCl}_{3}\right) \delta: 0.90(3 \mathrm{H}, \mathrm{t}$, $J=7.1 \mathrm{~Hz}), 1.20-1.53(2 \mathrm{H}, \mathrm{m}), 2.01(2 \mathrm{H}, \mathrm{q}, J=6.7 \mathrm{~Hz}), 2.63(2 \mathrm{H}, \mathrm{q}$, $J=6.7 \mathrm{~Hz}), 3.13(2 \mathrm{H}, \mathrm{t}, J=7.2 \mathrm{~Hz}), 5.29(1 \mathrm{H}, \mathrm{m}), 5.38(1 \mathrm{H}, \mathrm{m})$.

3(Z)-Heptenyltriphenylphosphonyl Iodide (23) $\mathrm{PPh}_{3}(123.5 \mathrm{mg})$ was added to a solution of $\mathbf{2 2}(70.4 \mathrm{mg})$ in acetonitrile $(5 \mathrm{ml})$ and the whole was stirred at $90^{\circ} \mathrm{C}$ for $24 \mathrm{~h}$. After the mixture was then allowed to stand at room temperature for $24 \mathrm{~h}$, the reaction mixture was concentrated under vacuum. The residue was washed with diethyl ether. A colorless solid was obtained almost quantitatively, and this compound was employed in the next reaction without purification. ${ }^{1} \mathrm{H}-\mathrm{NMR}\left(\mathrm{CDCl}_{3}\right) \delta: 0.82(3 \mathrm{H}, \mathrm{m}), 1.15-1.40(2 \mathrm{H}$, m), $1.50-1.90(2 \mathrm{H}, \mathrm{m}), 2.30-2.60(2 \mathrm{H}, \mathrm{m}), 3.52-3.83(2 \mathrm{H}, \mathrm{m}), 5.46(1 \mathrm{H}$, $\mathrm{m}), 5.54(1 \mathrm{H}, \mathrm{m}), 7.75-7.97(15 \mathrm{H}, \mathrm{m})$.

6-Hepten-3-ynol (24) A solution of $19(490.6 \mathrm{mg})$ in THF $(3 \mathrm{ml})$ was successively added dropwise to a solution of EtMgBr in THF $(0.9 \mathrm{M}$, $23.3 \mathrm{ml}$ ) with stirring, and the mixture was stirred at $40{ }^{\circ} \mathrm{C}$ for $1 \mathrm{~h}$ under a nitrogen atmosphere. After a solution of allyl iodide $(3.5 \mathrm{~g})$ in THF $(5 \mathrm{ml})$ was added to this solution, the whole was stirred for $20 \mathrm{~min}$. And then $\mathrm{CuCl}$ $(21 \mathrm{mg})$ was added to the reaction mixture, the whole was refluxed for $1 \mathrm{~h}$. The reaction mixture was quenched with cold water and upper solution was removed by decantation. The precipitate was dissolved in THF, dried and concentrated. The residue was subjected to silica gel chromatography (hexane : $\mathrm{AcOEt}=4: 1)$ to yield $695.7 \mathrm{mg}(90.4 \%)$ of $\mathbf{2 4}$ as a colorless oil. IR $v_{\max }^{\mathrm{KBr}} \mathrm{cm}^{-1}: 3352,1650 .{ }^{1} \mathrm{H}-\mathrm{NMR}\left(\mathrm{CDCl}_{3}\right) \delta: 1.83(1 \mathrm{H}, \mathrm{brs}), 2.48(2 \mathrm{H}, \mathrm{m})$, $2.97(2 \mathrm{H}, \mathrm{m}), 3.71(2 \mathrm{H}, \mathrm{q}, J=5.4 \mathrm{~Hz}), 5.11(1 \mathrm{H}, \mathrm{dt}, J=10.0,1.7 \mathrm{~Hz}), 5.31$ $(1 \mathrm{H}, \mathrm{dt}, J=16.9,1.7 \mathrm{~Hz}), 5.84(1 \mathrm{H}, \mathrm{m})$.

3(Z),6-Heptadienol (25) A mixture of Lindlar's catalyst $\left(\mathrm{Pd} \mathrm{CaCO}_{3}\right.$, $100 \mathrm{mg})$, quinoline $(50 \mu \mathrm{l})$ and $\mathbf{2 4}(550 \mathrm{mg})$ in hexane $(20 \mathrm{ml})$ was stirred at room temperature for $16 \mathrm{~h}$ under $\mathrm{H}_{2}$. After the mixture was filtered, $10 \%$ $\mathrm{HCl}$ was added to the filter liquid and extracted with diethyl ether. The organic layer was washed with saturated $\mathrm{NaCl}$ solution, dried and concentrated. The residue was subjected to silica gel chromatography (hexane : $\mathrm{AcOEt}=2: 1)$ to yield $421.6 \mathrm{mg}(75.3 \%)$ of $\mathbf{2 5}$ as a colorless oil. IR $v_{\max }^{\mathrm{KBr}} \mathrm{cm}^{-1}: 3350,1640 .{ }^{1} \mathrm{H}-\mathrm{NMR}\left(\mathrm{CDCl}_{3}\right) \delta: 2.34(2 \mathrm{H}, \mathrm{q}, J=6.3 \mathrm{~Hz}), 2.84$ $(2 \mathrm{H}, \mathrm{q}, J=6.4 \mathrm{~Hz}), 3.66(2 \mathrm{H}, \mathrm{q}, J=6.0 \mathrm{~Hz}), 4.95(1 \mathrm{H}, \mathrm{m}), 5.15(1 \mathrm{H}, \mathrm{m}), 5.41$ $(1 \mathrm{H}, \mathrm{m}), 5.53(1 \mathrm{H}, \mathrm{m}), 5.68(1 \mathrm{H}, \mathrm{m})$.

1-Iodo-3(Z),6-heptadiene (26) A solution of $\mathrm{PPh}_{3}(952 \mathrm{mg})$ and imidazole $(247 \mathrm{mg})$ in a mixture of diethyl ether and acetonitrile $(3: 1,60 \mathrm{ml})$ was stirred at $0^{\circ} \mathrm{C}$ for $10 \mathrm{~min}$ and then iodine $(922 \mathrm{mg}$ ) was added to this solution, the whole was stirred at $0{ }^{\circ} \mathrm{C}$ for $15 \mathrm{~min}$. A solution of $\mathbf{2 5}(135.3 \mathrm{mg})$ in mixture of diethyl ether and acetonitrile $(3: 1,1 \mathrm{ml})$ was added to this solution with stirring at $0{ }^{\circ} \mathrm{C}$. The mixture was then allowed to stand at room temperature for $1 \mathrm{~h}$. The reaction mixture was treated with saturated $\mathrm{NaHCO}_{3}$ solution and extracted with diethyl ether. The organic layer was washed with saturated $\mathrm{NaCl}$ solution, dried and concentrated. The residue was subjected to silica gel chromatography (hexane : $\mathrm{AcOEt}=9: 1$ ) to yield $70.4 \mathrm{mg}(65.5 \%)$ of $\mathbf{2 6}$ as a colorless oil. IR $v_{\max }^{\mathrm{KBr}} \mathrm{cm}^{-1}: 1640 .{ }^{1} \mathrm{H}-\mathrm{NMR}$ $\left(\mathrm{CDCl}_{3}\right) \delta: 2.55-2.95(4 \mathrm{H}, \mathrm{m}), 3.15(2 \mathrm{H}, \mathrm{t}, J=7.3 \mathrm{~Hz}), 4.95-5.30(2 \mathrm{H}$, m), $5.35-6.05(3 \mathrm{H}, \mathrm{m})$

3(Z),6-Heptadienyltriphenylphosphonium Iodide (27) $\mathrm{PPh}_{3}(105.0 \mathrm{mg})$ was added to a solution of $\mathbf{2 6}(68.3 \mathrm{mg})$ in acetonitrile $(5 \mathrm{ml})$, the whole was 
stirred at $90^{\circ} \mathrm{C}$ for $24 \mathrm{~h}$. After the mixture was then allowed to stand at room temperature for $24 \mathrm{~h}$, the reaction mixture was concentrated under vacuum. The residue was washed with diethyl ether. A colorless solid was obtained almost quantitatively, and this compound was employed in the next reaction without purification. ${ }^{1} \mathrm{H}-\mathrm{NMR}\left(\mathrm{CDCl}_{3}\right) \delta: 2.32-2.70(4 \mathrm{H}, \mathrm{m}), 3.67-3.95$ $(2 \mathrm{H}, \mathrm{m}), 4.75-4.15(2 \mathrm{H}, \mathrm{m}), 5.30-5.85(3 \mathrm{H}, \mathrm{m}), 7.20-8.07(15 \mathrm{H}, \mathrm{m})$.

Ethyl 2-Methoxy-6-[8(Z),11(Z)-pentadecadienyl]benzoate (28) BuLi in hexane $(1.58 \mathrm{M}, 89 \mathrm{ml})$ was successively added dropwise to a stirred solution of $23(68.4 \mathrm{mg})$ in THF $(2 \mathrm{ml})$ at room temperature under a nitrogen atmosphere. After $1 \mathrm{~h}$, a solution of $\mathbf{1 5}(10.9 \mathrm{mg})$ in THF $(1 \mathrm{ml})$ was added to the reaction mixture and the whole was stirred at room temperature for 30 min under a nitrogen atmosphere. And then the reaction mixture was quenched with cold water, extracted with AcOEt, washed with saturated $\mathrm{NaCl}$, dried $\left(\mathrm{MgSO}_{4}\right)$ and concentrated. The residue was subjected to silica gel chromatography (hexane : AcOEt $=9: 1)$ to yield $9.0 \mathrm{mg}(66.7 \%)$ of $\mathbf{2 8}$ as a colorless oil. IR $v_{\max }^{\mathrm{KBr}} \mathrm{cm}^{-1}: 1730,1600,1580,1480 .{ }^{1} \mathrm{H}-\mathrm{NMR}\left(\mathrm{CDCl}_{3}\right) \delta$ : $0.91(3 \mathrm{H}, \mathrm{t}, J=7.3 \mathrm{~Hz}), 1.26-1.42(12 \mathrm{H}, \mathrm{m}), 1.36(3 \mathrm{H}, \mathrm{t}, J=7.2 \mathrm{~Hz}), 2.04$ $(4 \mathrm{H}, \mathrm{m}), 2.55(2 \mathrm{H}, \mathrm{t}, J=7.9 \mathrm{~Hz}), 2.77(2 \mathrm{H}, \mathrm{t}, J=5.6 \mathrm{~Hz}), 3.81(3 \mathrm{H}, \mathrm{s}), 4.39$ $(2 \mathrm{H}, \mathrm{q}, J=7.1 \mathrm{~Hz}), 5.32-5.40(4 \mathrm{H}, \mathrm{m}), 6.75(1 \mathrm{H}, \mathrm{d}, J=7.9 \mathrm{~Hz}), 6.81(1 \mathrm{H}, \mathrm{d}$, $J=7.9 \mathrm{~Hz}), 7.26(1 \mathrm{H}, \mathrm{t}, J=7.9 \mathrm{~Hz}$ ). High-MS $m / z$ : 386.2833 (Calcd for $\left.\mathrm{C}_{24} \mathrm{H}_{38} \mathrm{O}_{3}: 386.2821\right)$.

Ethyl $[8(Z), 11(Z)$-Pentadecadienyl]salicylate (29) A solution of 28 $(10.9 \mathrm{mg})$ in absolute $\mathrm{CH}_{2} \mathrm{Cl}_{2}$ was added to a solution of $\mathrm{BBr}_{3}(5.4 \mu \mathrm{l})$ in anhydrous $\mathrm{CH}_{2} \mathrm{Cl}_{2}$ at $0{ }^{\circ} \mathrm{C}$ under a nitrogen, and the whole was stirred at room temperature for $1 \mathrm{~h}$ under a nitrogen. And then the reaction mixture was quenched with cold water and extracted with $\mathrm{CH}_{2} \mathrm{Cl}_{2}$. The organic layer was washed with saturated $\mathrm{NaCl}$ solution, dried $\left(\mathrm{MgSO}_{4}\right)$ and concentrated. The residue was subjected to silica gel chromatography (hexane : $\mathrm{AcOEt}=9: 1$ ) to yield $10.2 \mathrm{mg}(97.1 \%)$ of 29 as a colorless oil. IR $v_{\max }^{\mathrm{KBr}} \mathrm{cm}^{-1}: 1660,1610$, 1580. ${ }^{1} \mathrm{H}-\mathrm{NMR}\left(\mathrm{CDCl}_{3}\right) \delta: 0.88(3 \mathrm{H}, \mathrm{t}, J=7.3 \mathrm{~Hz}), 1.22-1.60(12 \mathrm{H}, \mathrm{m})$, $1.43(3 \mathrm{H}, \mathrm{t}, J=7.2 \mathrm{~Hz}), 1.94-2.07(4 \mathrm{H}, \mathrm{m}), 2.75(2 \mathrm{H}, \mathrm{m}), 2.95(2 \mathrm{H}, \mathrm{t}$, $J=7.8 \mathrm{~Hz}), 4.44(2 \mathrm{H}, \mathrm{q}, J=7.3 \mathrm{~Hz}), 5.32-5.43(4 \mathrm{H}, \mathrm{m}), 6.71(1 \mathrm{H}, \mathrm{dd}$, $J=7.9,1.2 \mathrm{~Hz}), 6.83(1 \mathrm{H}, \mathrm{dd}, J=7.9,1.2 \mathrm{~Hz}), 7.28(1 \mathrm{H}, \mathrm{t}, J=7.9 \mathrm{~Hz}) 11.24$ $(1 \mathrm{H}, \mathrm{s})$. High-MS $m / z$ : 372.2664 (Calcd for $\left.\mathrm{C}_{24} \mathrm{H}_{36} \mathrm{O}_{3}: 372.2664\right)$.

6-[8(Z),11(Z)-Pentadecadienyl]salicylic Acid (3) A solution of 29 $(4.0 \mathrm{mg})$ in EtOH $(1 \mathrm{ml})$ and $10 \% \mathrm{NaOH}(1 \mathrm{ml})$ was refluxed for $6 \mathrm{~h}$. The reaction mixture was then acidified with $10 \% \mathrm{HCl}$ and extracted with $\mathrm{CHCl}_{3}$. The organic layer was washed with saturated $\mathrm{NaCl}$ solution, dried and concentrated. The residue was subjected to silica gel chromatography (AcOEt) to yield $3.2 \mathrm{mg}(86.5 \%)$ of 3 as a brown oil. IR $v_{\max }^{\mathrm{KBr}} \mathrm{cm}^{-1}: 1700,1680,1660$, 1650, 1640, 1605, 1580, 1450. ${ }^{1} \mathrm{H}-\mathrm{NMR}\left(\mathrm{CDCl}_{3}\right) \delta: 0.90(3 \mathrm{H}, \mathrm{t}, J=6.9 \mathrm{~Hz})$, $1.05-1.70(12 \mathrm{H}, \mathrm{m}), 1.89-2.27(4 \mathrm{H}, \mathrm{m}), 2.77(2 \mathrm{H}, \mathrm{t}, J=5.7 \mathrm{~Hz}), 2.95(2 \mathrm{H}$, $\mathrm{t}, J=6.4 \mathrm{~Hz}), 5.27-5.45(4 \mathrm{H}, \mathrm{m}), 6.75(1 \mathrm{H}, \mathrm{d}, J=8.4 \mathrm{~Hz}), 7.34(1 \mathrm{H}, \mathrm{d}$, $J=8.4 \mathrm{~Hz}) 7.85(1 \mathrm{H}, \mathrm{d}, J=8.4 \mathrm{~Hz}$ ). High-MS $m / z: 344.2345$ (Calcd for $\left.\mathrm{C}_{22} \mathrm{H}_{32} \mathrm{O}_{3}: 344.2350\right)$.

Ethyl 2-Methoxy-6-[8(Z),11(Z),14-pentadecatrienyl]benzoate (30) BuLi in hexane $(1.58 \mathrm{M}, 190 \mu \mathrm{l})$ was successively added dropwise to a stirred solution of $27(138 \mathrm{mg})$ in THF $(2 \mathrm{ml})$ at room temperature under a nitrogen atmosphere. After $1 \mathrm{~h}$, a solution of $\mathbf{1 5}(21.8 \mathrm{mg})$ in THF $(1 \mathrm{ml})$ was added to the reaction mixture and the whole was stirred at room temperature for $30 \mathrm{~min}$ under nitrogen. And then the reaction mixture was quenched with cold water, extracted with AcOEt, washed with saturated $\mathrm{NaCl}$, dried $\left(\mathrm{MgSO}_{4}\right)$ and concentrated. The residue was subjected to silica gel chromatography (hexane : $\mathrm{AcOEt}=9: 1$ ) to yield $18.9 \mathrm{mg}(69.3 \%)$ of $\mathbf{3 0}$ as a colorless oil. IR $v_{\max }^{\mathrm{KBr}} \mathrm{cm}^{-1}: 1730,1600,1580,1480 .{ }^{1} \mathrm{H}-\mathrm{NMR}\left(\mathrm{CDCl}_{3}\right) \delta$ : $1.15-1.75(10 \mathrm{H}, \mathrm{m}), 1.37(3 \mathrm{H}, \mathrm{t}, J=7.1 \mathrm{~Hz}), 1.90-2.18(2 \mathrm{H}, \mathrm{m}), 2.55(2 \mathrm{H}$, $\mathrm{t}, J=7.7 \mathrm{~Hz}), 2.65-2.98(4 \mathrm{H}, \mathrm{m}) 3.81(3 \mathrm{H}, \mathrm{s}), 4.39(2 \mathrm{H}, \mathrm{q}, J=7.1 \mathrm{~Hz}), 5.05$ $(2 \mathrm{H}, \mathrm{m}), 5.29-5.50(4 \mathrm{H}, \mathrm{m}), 5.78(1 \mathrm{H}, \mathrm{m}), 6.75(1 \mathrm{H}, \mathrm{d}, J=7.7 \mathrm{~Hz}), 6.80$ $(1 \mathrm{H}, \mathrm{d}, J=7.7 \mathrm{~Hz}), 7.26(1 \mathrm{H}, \mathrm{t}, J=7.7 \mathrm{~Hz})$. High-MS $m / z: 384.2665$ (Calcd for $\left.\mathrm{C}_{25} \mathrm{H}_{36} \mathrm{O}_{3}: 384.2664\right)$.

Ethyl [8(Z),11(Z),14-Pentadecatrienyl]salicylate (31) A solution of 30 $(10.9 \mathrm{mg})$ in anhydrous $\mathrm{CH}_{2} \mathrm{Cl}_{2}$ was added to a solution of $\mathrm{BBr}_{3}(3.8 \mu \mathrm{l})$ in anhydrous $\mathrm{CH}_{2} \mathrm{Cl}_{2}$ at $0{ }^{\circ} \mathrm{C}$ under nitrogen, and the whole was stirred at room temperature for $1 \mathrm{~h}$ under nitrogen. And then the reaction mixture was quenched with cold water, extracted with $\mathrm{CH}_{2} \mathrm{Cl}_{2}$. The organic layer was washed with saturated $\mathrm{NaCl}$ solution, dried $\left(\mathrm{MgSO}_{4}\right)$ and concentrated. The residue was subjected to silica gel chromatography (hexane : AcOEt $=9: 1$ ) to yield $4.5 \mathrm{mg}(75.0 \%)$ of 31 as a colorless oil. IR $v_{\max }^{\mathrm{KBr}} \mathrm{cm}^{-1}: 3400,1740$, 1660, 1610, 1580. ${ }^{1} \mathrm{H}-\mathrm{NMR}\left(\mathrm{CDCl}_{3}\right) \delta: 1.12-1.70(10 \mathrm{H}, \mathrm{m}), 1.43(3 \mathrm{H}, \mathrm{t}$, $J=7.2 \mathrm{~Hz}), 1.90-2.10(2 \mathrm{H}, \mathrm{m}), 2.70-2.98(6 \mathrm{H}, \mathrm{m}), 4.44 \quad(2 \mathrm{H}, \mathrm{q}$, $J=7.2 \mathrm{~Hz}), 5.04(2 \mathrm{H}, \mathrm{m}), 5.29-5.52(4 \mathrm{H}, \mathrm{m}), 5.80(1 \mathrm{H}, \mathrm{m}), 6.72(1 \mathrm{H}, \mathrm{d}$, $J=8.7 \mathrm{~Hz}), 6.81(1 \mathrm{H}, \mathrm{d}, J=.7 \mathrm{~Hz}), 7.29(1 \mathrm{H}, \mathrm{d}, J=8.7 \mathrm{~Hz}), 11.21(1 \mathrm{H}, \mathrm{s})$. High-MS $m / z$ : 370.2540 (Calcd for $\mathrm{C}_{24} \mathrm{H}_{34} \mathrm{O}_{3}: 370.2508$ ).

6-[8(Z),11(Z),14-Pentadecatrienyl]salicylic Acid (4) A solution of 31 $(4.5 \mathrm{mg})$ in $\mathrm{EtOH}$ and $10 \% \mathrm{NaOH}(1 \mathrm{ml})$ was refluxed for $6 \mathrm{~h}$. The reaction mixture was then acidified with $10 \% \mathrm{HCl}$ and extracted with $\mathrm{CHCl}_{3}$. The organic layer was washed with saturated $\mathrm{NaCl}$ solution, dried and concentrated. The residue was subjected to silica gel chromatography (AcOEt) to yield $3.7 \mathrm{mg}(88.5 \%)$ of 4 as a brown oil. IR $v_{\max }^{\mathrm{KBr}} \mathrm{cm}^{-1}: 1700,1660,1650$, $1605,1580 .{ }^{1} \mathrm{H}-\mathrm{NMR}\left(\mathrm{CDCl}_{3}\right) \delta: 1.10-1.70(10 \mathrm{H}, \mathrm{m}), 1.90-2.13(2 \mathrm{H}, \mathrm{m})$, $2.70-3.05(6 \mathrm{H}, \mathrm{m}), 4.90-5.20(2 \mathrm{H}, \mathrm{m}), 5.20-5.50(4 \mathrm{H}, \mathrm{m}), 5.55-6.00$ $(1 \mathrm{H}, \mathrm{m}), 6.76(1 \mathrm{H}, \mathrm{d}, J=7.9 \mathrm{~Hz}), 6.85(1 \mathrm{H}, \mathrm{d}, J=7.9 \mathrm{~Hz}), 7.35(1 \mathrm{H}, \mathrm{d}$, $J=7.9 \mathrm{~Hz}$ ). High-MS $m / z: 342.2225$ (Calcd for $\mathrm{C}_{22} \mathrm{H}_{30} \mathrm{O}_{3}: 342.2195$ ).

\section{References}

1) Paul V. J., Yeddanapalli L. M., Nature (London), 174, 604 (1954).

2) Kubo I., Himejima M., J. Agric. Food Chem., 39, 418-421 (1991).

3) Mumma R. O., Biochem. Biophys. Res. Commun., 176, 775-780 (1991).

4) Nishino C., Kobayashi K., Tamao Y., Ohya J., Jpn. Kokai Tokkyo Koho, 67-72 (1989).

5) Kubo I., Yamagiwa Y., Ohashi K., Sakamoto Y., Hirakawa S., Kamikawa T., Tetrahedron, 43, 3387-3394 (1987).

6) Durrani A. A., Tyman J. H. P., J. Chem. Soc., Perkin Trans. 1, 1979, $2069-2078$

7) Durrani A. A., Tyman J. H. P., J. Chem. Soc., Perkin Trans. 1, 1979, 2079-2087.

8) Tyman J. H. P., J. Org. Chem., 41, 894 (1976).

9) Satoh M., Takeuchi N., Fujita T., Yamazaki K., Tobinaga S., Chem. Pharm. Bull., 46, 1501-1505 (1998).

10) Satoh M., Takeuchi N., Fujita T., Yamazaki K., Nishimura T., Tobinaga S., Chem. Pharm. Bull., 47, 1115-1116 (1999). 